Ks. Jarosław ADAMIAK*

\title{
MOTY AURORY W ANTYCZNEJ POEZJI CHRZEŚCIJAŃSKIEJ
}

Wielokrotnie spotykamy w poezji klasycznej, a zwłaszcza w eposie, obraz Jutrzenki, bogini poranka, poprzedzającej wschodzące Słońce, który kontrastuje z wojennymi obrazami, właściwymi dla tego gatunku. Obecna w greckim panteonie bogini Eos, o której wspomina Hezjod w Teogonii ${ }^{1}$ staje się z kolei elementem topiki eposów Homera, gdzie pojawia się często w utartych formułach, noszących znamię rozbudowanych określeń czasu ${ }^{2}$. Z eposu greckiego w naturalny sposób zostaje przeniesiona jako Aurora do poezji rzymskiej, gdzie można ją znaleźć u Wergiliusza i to zarówno w eposie o dziejach Eneasza $^{3}$, jak i w dydaktycznych Georgikach ${ }^{4}$, noszących znamiona poezji lirycznej. Aurorę spotka także czytelnik elegijnej twórczości Owidiusza, zwłaszcza w epickich co do formy Metamorfozach ${ }^{5}$. Pozostawiając oddzielnemu opracowaniu kwestię znaczenia motywu jutrzenki w pogańskiej poezji, chciałbym tu przyjrzeć się dziełom starożytnych poetów chrześcijańskich, którzy obficie korzystali z dorobku antycznej kultury, wykorzystując nie tylko poetyckie formy od strony gatunkowej, ale także od strony motywów, które z poszczególnymi gatunkami były powiązane. Celem artykułu jest analiza sposobów wykorzystania motywu jutrzenki przez nową poezję oraz ukazanie wielorakich powiązań formalnych i treściowych z klasyczną twórczością grecką i łacińską.

\footnotetext{
* Ks. mgr Jarosław Adamiak - doktorant przy Katedrze Literatury Wczesnochrześcijańskiej w Instytucie Filologii Klasycznej na Wydziale Nauk Humanistycznych Katolickiego Uniwersytetu Lubelskiego Jana Pawła II; e-mail: herezjarha@wp.pl.

${ }^{1}$ Por. Hesiodus, Theogonia 19; 372; 984.

${ }^{2}$ Najsłynniejszy obraz to różanopalca jutrzenka (Homerus, Ilias VI 175, ed. G. Dindorf: Homeri Ilias, I, Lipsiae 19275 , 118; XXIII 109, ed. Dindorf, II, Lipsiae 19255 , 213; w szafranowym płaszczu (tamże VIII 1, ed. Dindorf, I, s. 145; XXIII 277, ed. Dindorf, II, 217; XXIV 695, ed. Dindorf, II, 261). W obu poematach Homera można wskazać jeszcze wiele analogicznych miejsc, których przytoczenie nie jest tu konieczne, wszystkie jednak stanowią najczęściej rozbudowaną formę określenia czasu, którą można zastąpić prostym „o świcie”.

${ }^{3}$ Charakterystyczne przykłady: Publius Vergilius Maro, Aeneis III 521; IV 6-7; 584-585; VII 25; X 241; XI 182.

${ }^{4}$ Por. tenże, Georgica I 250; 445-448.

${ }^{5}$ Niektóre przykłady: Ovidius, Metamorphoses II 111; 144; V 440; IX 421-422, a także w kontekście mitu Kefalosa i Prokris: tamże VII 700-837; tenże, Epistulae vel Heroides IV 95-96; tenże, Amores I 13, 1-3; II 4, 43.
} 
Materiałem badawczym będą tu fragmenty dzieł poetów łacińskich od III w. po późny antyk, którzy tworzyli zasadniczo dwie oddzielne kategorie utworów, mianowicie poezję bezpośrednio naśladującą formy klasyczne, tematycznie zaś odnoszącą się do chrześcijaństwa, choć niekiedy jedynie w sposób aluzyjny oraz poezję ściśle religijną, przeznaczoną bądź to do użytku liturgicznego, bądź to do osobistej medytacji. Do pierwszej kategorii można zaliczyć utwory Laktancjusza, Sydoniusza Apolinarego, Prudencjusza, Drakoncjusza i Paulina z Périgueux; do drugiej Ambrożego, ponownie Prudencjusza oraz kilka utworów anonimowych. Wspólnym mianownikiem prezentowanych i analizowanych tekstów będzie obecność klasycznego motywu Aurory.

1. Chrześcijańscy naśladowcy dawnych wzorów. Łacińska i grecka literatura to spuścizna kultury, w której orbicie narodziło się chrześcijaństwo, jakkolwiek miało swe źródła w religii i kulturze judaistycznej. Z czasem jednak nastąpiło spotkanie dwóch światów: świata religii i kultury antycznego Rzymu z nową religią, która stopniowo krzepła i przybierała swój właściwy, historycznie trwały kształt, zwłaszcza po roku 313. Od strony politycznej, religijnej i obyczajowej nieuchronna była konfrontacja, ponieważ chrześcijaństwo proponowało radykalne odwrócenie dotychczasowych zasad moralnych i religijnych. Konfrontacja ta oznaczała jednak nie tylko napięcia, ale i dialog który wynikał z wzajemnego doceniania walorów obu stron. Dialog zaś był możliwy dzięki wspólnemu językowi i dostosowywaniu przez chrześcijan form przekazu do sposobu myślenia właściwego kulturze grecko-rzymskiej. Wejście chrześcijaństwa w tę orbitę oznaczało nie tylko przemianę świata antycznego, ale też samego chrześcijaństwa, które mogło rozwinąć własną myśl teologiczną w oparciu klasyczną, a także własną poezję, łącząc treści i formy wyrosłe z Biblii ze spuścizną poezji antyku pogańskiego. Najwięksi twórcy chrześcijańskiego antyku kształcili się na dawnych mistrzach, znali ich poezję, uczyli się retoryki, a ich twórczość często zaczynała się od imitatio $^{6}$.

Swoistym pomostem między antykiem pogańskim a chrześcijańską poezją jest elegia o Feniksie, przypisywana Laktancjuszowi ${ }^{7}$. De ave Phoenice to utwór podejmujący stary, opracowywany już przez Herodota, potem przez Owidiusza i innych, mit ptaka, który odradza się z własnych popiołów, co stanowiło samo $\mathrm{w}$ sobie symbol ${ }^{8}$, wykorzystywany chętnie przez chrześcijań-

${ }^{6}$ Por. H. Marrou, Historia wychowania w starożytności, tłum. S. Łoś, Warszawa 1969, 444.

${ }^{7}$ L. Caecilius Firmianus Lactantius, świetnie wykształcony filozoficznie i literacko nauczyciel wymowy łacińskiej, sympatyzując z chrześcijaństwem tworzył dzieła apologetyczne w gorącym okresie przełomu III i IV wieku. Por. M. Cytowska - H. Szelest, Literatura rzymska. Okres cesarstwa - autorzy chrześcijańscy, Warszawa 1994, 85.

${ }^{8}$ Istnieją element wiążące egipskie wyobrażenie boga Słońca jako ptaka z przypisaniem Feniksowi funkcji sługi Feba przez Laktancjusza, por. T.P. Harrison, Bird of Paradise: Phoenix Redivivus, „Isis” 51 (1960) 173. 
skich autorów z powodu zbieżności trzydniowego oczekiwania na odrodzenie Feniksa ze zmartwychwstaniem Chrystusa ${ }^{9}$. Poemat Laktancjusza jest dziełem dwuznacznym, jeśli chodzi o interpretację, ponieważ inaczej spoglądał na niego niechrześcijanin, inaczej wyznawca Chrystusa. $Z$ jednej strony Laktancjusz przedstawia obraz zgodny z mitologiczną tradycją, pokazuje Feniksa jako sługę boga słońca, Feba, z drugiej strony opis rajskiej ojczyzny ptaka i jego codzienna służba przywodzi na myśl życie człowieka zbawionego, a jego odrodzenie z popiołów przypomina zmartwychwstanie Chrystusa ${ }^{10}$. Jest to całościowe przedstawienie mitu na sposób analogiczny do Owidiusza, a jednak wykorzystane jako argument za nieśmiertelnością człowieka ${ }^{11}$. Feniks, przebywając w swej rajskiej krainie, oczekuje każdego ranka na pojawienie się Słońca, któremu służy, a które poprzedza Aurora:

„Lutea cum primum surgens Aurora rubescit, cum primum rosea sidera luce fugat, ter quater illa pias inmergit corpus in undas: ter, quater e vivo gurgite libat aquam.

Tollitur, ac summo consedit in arboris altae vertice, quae totum despicit una nemus:

et conversa novos Phoebi nascentis ad ortus, expectat radios, et iubar exoriens" ${ }^{\prime 12}$.

Bogini poranka, jak to miało miejsce w poezji klasycznej, podnosi się i pokrywa czerwienią niebo zmuszając do ucieczki gwiazdy, które ustępują przed pierwszym światłem, mającym barwę różaną. Widać więc epicki topos, który, głównie za sprawą elegijnej poezji Owidiusza, przeszedł do innych gatunków.

Sydoniusz Apolinary (Caius Sollius Modestus Apollinaris Sidonius), którego życie przypada na okres ostatecznego unicestwienia politycznego Zachodniego Cesarstwa jest kolejnym twórcą, u którego widoczne są silne wpływy wzorów pogańskiego antyku ${ }^{13}$. W twórczości Sydoniusza dominuje

\footnotetext{
${ }^{9}$ Por. M.F. Donald, Phoenix Redivivus, „Phoenix” 14 (1960) 200.

${ }^{10}$ Por. Cytowska - Szelest, Literatura rzymska, s. 97.

${ }^{11}$ Por. Donald, Phoenix Redivivus, s. 201-202.

${ }^{12}$ Incerti auctoris Phoenix Lactantio tributus 35-42, PL 7, 278-279, tłum. własne: „Gdy Ju-
} trzenka o brzasku niebo zaróżowi / i niewodem światła blade gwiazdy złowi, / ptak ów dwanaście razy w źródle się zanurza, / pije wodę chłodną, znowu się wynurza, / zaraz siada na drzewie rosnącym nad gajem / i z wysoka spojrzy ponad całym krajem. / Na wschód patrzy, czekając febowego blasku / i wygląda chciwie promiennego brzasku".

${ }^{13}$ Sydoniusz (ok. 430-485) był przede wszystkim poetą i pisarzem, ale też aktywnym uczestnikiem życia publicznego w Galii, z której pochodził, a która wówczas jedynie w niewielkiej części pozostawała pod panowaniem Rzymu. Sydoniusz był członkiem arystokracji i dlatego jego wykształcenie gramatyczne i retoryczne oraz filozoficzne było ukierunkowane na karierę urzędniczą. Por. M. Brożek, Wstęp, w: Sydoniusz Apolinary, Listy i wiersze, tłum. i oprac. M. Brożek, Kraków 2004, V-VI. 
poezja panegiryczna, pisana - wzorem dawnych mistrzów - między innymi heksametrem i dystychem elegijnym ${ }^{14}$. Interesujący z punktu widzenia naszego tematu jest utwór Burgus Pontii Leontii (Carmen XXII) pisany heksametrem, liczący 235 wersów, opisujący posiadłość przyjaciela poety, Pontiusa Leontiusa. W utworze umieścił nie tylko opis posiadłości, ale także bóstwa i uczonych, którzy podziwiają piękno Burgus. Na wstępie twórca prosi Erato o wsparcie dzieła:

„Ergo age, Pierias Erato mihi percute chordas [...]"15.

Urok posiadłości przyciąga także bóstwa, tak że spotykają się idące ku niej orszaki Apollina wraz z muzami oraz otoczonego przez nimfy, satyry i fauny Bachusa, który zmierza do Teb. W pewnym momencie pojawia się też postać Aurory zniżającej ku ziemi szafranowe policzki, która czerwieni świat pochodnią i promieniami słońca:

„Nec non et rapti conjux ibi vincta mariti

it croceas demissa genas, vetitaque recondi

lampade cum Solis radiis Aurora rubebat" ${ }^{\prime 16}$.

Widać tu klasyczny, niemal wergiliański obraz Aurory, co wynika z faktu, że Wergiliusz należał do wzorców poety pod względem wyrażeń i motywów, tak jak Klaudian pod względem konstrukcji poematów ${ }^{17}$. Owe klasyczne elementy to: szafranowa barwa, tym razem związana nie z szatą, czy włosami bogini, ale $\mathrm{z}$ jej policzkami ${ }^{18}$, widać topos nie wymienionego $\mathrm{z}$ imienia Titonosa, widać wreszcie echo czerwonej barwy w czasowniku rubeo ${ }^{19}$. Oto obraz Jutrzenki z całym sztafarzem boskich atrybutów, jakie przydzieliła jej epika grecka i potem rzymska, a wszystko to $\mathrm{w}$ utworze przyszłego chrześcijańskiego biskupa $^{20}$ ! Jest to przykład na ogromny wpływ, jaki na twórczość przyszłych wieków wywarły dzieła klasyków. Sydoniusz w młodości uczył się przecież gramatyki i retoryki korzystając z pogańskiej literatury.

\footnotetext{
${ }^{14}$ Por. Cytowska - Szelest, Literatura rzymska, s. 337-353.

${ }^{15}$ Sidonius Apollinaris, Carmen XXII 12, PL 58, 72, tłum. własne: „Erato, Pierus cię uczcił, w struny moje uderz!”.

${ }^{16}$ Tenże, Carmen XXII 47-49, PL 58, 726, tłum. własne: „Żona, co męża porwała, także tutaj bieży, / lica z szafranu pochyla, skryć się jej nie wolno: / już się czerwieni Jutrzenka pochodnią z promieni".

${ }^{17}$ Por. Cytowska - Szelest, Literatura rzymska, s. 342.

${ }^{18}$ Klasyczny obraz u Wergiliusza (Aeneis IV 584-584, ed. O. Ribbeck, w: P. Vergili Maronis Opera cum Appendice, Lipsiae 1910, 189: „Et iam prima novo spargebat lumine terras / Tithoni croceum linquens Aurora cubile”, thum własne: „Oto o pierwszym brzasku światła ku ziemi rozsiewa, / łoże gdy męża, Tytona, Jutrzenka porzuca złociste").

${ }^{19}$ U Wergiliusza rubescere (Aeneis III 521, ed. Ribbeck, s. 164: „Iamque rubescebat stellis Aurora fugatis”, tłum. własne: „Już, gdy spędziła gwiazdy, Jutrzenka poczęła czerwienieć”).

${ }^{20} \mathrm{Ok}$. roku 470 Sydoniusz Apolinary został biskupem arwerneńskim; por. Brożek, Wstęp, s. VII.
} 
Ciekawy przykład wykorzystania toposu jutrzenki można znaleźć w heksametrycznym poemacie Drakoncjusza (Blossius Aemilius Dracontius), gruntownie wykształconego przedstawiciela arystokracji mieszkającej w Afryce rządzonej przez Wandalów ${ }^{21}$. Na skutek donosu poeta został uwięziony i poddany torturom fizycznym i moralnym. W tym czasie zwracając się o pomoc nie do władcy, lecz do Boga, napisał trzy księgi Carmen de Deo (lub Laudes $D e i)^{22}$. Pierwsza księga tego dzieła to epopeja biblijna, pochwała Boga Stwór$\mathrm{cy}^{23}$. Opis czwartego dnia stworzenia rozpoczyna się od jutrzenki, która uprzedza słońce czerwieniąc niebo:

„Auroram iam quarta dies praemiserat undis, et rutilante polo compresserat astra rubore.

Mox solis radiare globum iubet igne salutis:

flamma salutaris perfundit lumine mundum, cuncta salutifero rident elementa vapore, cuius ab igne suo lunam iubet ire secundam"24.

Widać tu typowy dla eposu obraz, w którym Aurora - raczej jako zjawisko, nie jako bogini - pojawia się na niebie, wynurzając się z oceanu i zapowiadając słońce. Znowu widać blednące gwiazdy i charakterystyczne barwy. Podobny obraz Drakoncjusz zaprezentował w tejże księdze nieco niżej, opisując wschód słońca, poprzedzony zblednięciem księżyca i porannej gwiazdy, Lucifer:
„Mortua lux sub luce cadit, perit aurea luna, atque per ascensus, et cornua colligit ignes, et dum caeca latet, reparato lumine fulget, mentiturque diem lux frigid, solis imago.
Lucifero redeunte polo moriuntur et astra.
Nuntius aurorae subductus morte diurnal
Lucifer exstinctas reficit per sidera flammas, et nocturnes eques jubar emicat igne corusco.
Roseida puniceum spargens aurora ruborem

${ }^{21}$ Poezję i wersyfikację przybliżył mu Felicjan, któremu młody poeta dedykował swoje pierwsze próby poetyckie o tematyce mitologicznej; por. M. Brożek, Drakoncjusz - poeta w więzieniu, „Meander” 35 (1980) 553. Poezja nie była, rzecz jasna jego głównym zajęciem, ponieważ Drakoncjusz poświęcił się karierze administracyjnej, do której przygotowywała go nauka retoryki; pełnił funkcję wysokiej rangi sędziego prokonsularnego jako vir togatus; por. tamże, s. 554. Kwestię pełnionej przez Drakoncjusza funkcji sędziego w świetle jego własnych dzieł ukazuje W. Schetter, Dracontius Togatus, „Hermes” 117 (1989) 342-350.

${ }^{22}$ Por. Brożek, Drakoncjusz, s. 558.

${ }^{23}$ Por. Cytowska - Szelest, Literatura rzymska, s. 358.

${ }^{24}$ Dracontius, Carmen de Deo I 204-209, PL 60, 707, tłum. własne: „Czwarty już dzień każe naprzód jutrzence $\mathrm{z}$ fali powstawać, / z nieba jasnego czerwienią gwiazdy nocne rozgonić. / Wkrótce zbawiennym światłem słońce świat opromieni, / zbawczych promieni światłością ziemię zaleje całą, / żywioł wszelki z weselem jaśnieć będzie od słońca, / które swym ogniem światłu księżyca odejść rozkaże". 
ducit ubique diem, periturum noctis ab umbris:

et tamen haec de sole perit, quo missa rubebat" ${ }^{\prime 25}$.

Efektowny opis świtu pokazuje kolejne kroki swoistego tańca niebiańskich zjawisk, które następują kolejno po sobie: zamiera księżyc, aby zrobić miejsce gwieździe porannej, ta ustępuje miejsca jutrzence, która z kolei zrobi miejsce słońcu, aby ono przeszło całą dzienną wędrówkę. Niewątpliwie malowniczość tego opisu przywodzi na myśl malarskie opisy świtu u Wergiliusza ${ }^{26}$. Jest to świadectwo obcowania poety z dziełami twórcy Aeneis, a także z Owidiuszem, Lukanem i innymi, których język i sposób obrazowania Drakoncjusz przejął, zdradzając także zdolność do improwizowania, do nowego ukazania tradycyjnych motywów ${ }^{27}$. Drakoncjusz jednak nie przedstawia tego obrazu jedynie dla efektu artystycznego, lecz traktuje go jako element pochwały Boga, której poświęcił całe swoje dzieło ${ }^{28}$.

Motyw jutrzenki znalazł się też w poświęconym świętemu Marcinowi poemacie Paulina z Périgueux (Paulinus de Petricordia) ${ }^{29}$. Opiewając życie i cnoty Świętego mówi o nocnych modlitwach mnichów, przy których zastaje ich jutrzenka:

${ }^{25}$ Tamże I 663-673, PL 60, 757-758, tłum. własne: „Światło zmarniałe przed światłem, złocisty księżyc zanika, / potem przez bieg swój rogami ogniste światła zagarnia, / czas jakiś blady się skryje, rozbłyska potem na nowo, / jasność udając słoneczną, choć chłodem blask ten przejmuje. / Gwiazda już zaszła poranna, gwiazdy wnet też umierają. / Świtu zwiastunka, codziennej śmierci się poddać zmuszona, / ranna gwiazda o zmierzchu niebiańskie płomyki przywraca, / jeźdźcem zaś w nocy się stając dobędzie znów świt migotliwy. / Sieje różana jutrzenka purpurę na ranne niebiosa, / wszędzie dzień przyprowadza, co zniknąć musi o zmierzchu: / przecież i ją zgładzi słońce, przed którym czerwienieć musiała".

${ }^{26}$ Podobny obraz widać w chwili, gdy o świcie Eneasz widzi po raz pierwszy ujście Tybru (Publius Vergilius Maro, Aeneis VII 25-34). Obraz ustępujących po sobie ciał niebieskich jest częsty u Wergiliusza, ale można go znaleźć także u Owidiusza (Metamorphoses II 111-118, ed. R. Merkelli: P. Ovidius Naso, Metamorphoses, Lipsiae 1905, 25: „Dumque ea magnanimus Phaethon miratur opusque / perspicit, ecce vigil rutilo patefecit ab ortu / purpureas Aurora fores et plena rosarum / atria. Diffugiunt stellae, quarum agmina cogit / Lucifer et caeli statione novissimus exit. / Quem petere ut terras mundumque rubescere vidit, / cornuaque extremae velut evanescere lunae: / iungere equos Titan velocibus imperat Horis”, thum. własne: „Gdy tak dzielny Faeton podziwia i dzieła / przepyszne widzi, czujna Jutrzenka od wschodu / wrota odmyka z purpury, przybytki w róże / strojne. W odwrocie gwiazd są gromady, bo Gwiazda / Ranna je zgania, a sama ostania zajdzie. / Gdy ją zobaczył Tytan, że ziemię i niebo czerwieni, / a Księżyc rogaty także znikać poczyna w końcu, / lotnym Godzinom dał rozkaz zaprzęgać konie").

${ }^{27}$ Por. Brożek, Drakoncjusz, s. 554.

${ }^{28}$ Taka deklaracja pojawia się dwukrotnie (Dracontius, Carmen de Deo 1, 749; 3, 736). Por. Cytowska - Szelest, Literatura rzymska, s. 359-60.

${ }^{29}$ Tworzący w V w. autor czerpał z Sulpicjusza Sewera oraz z opisu cudów przy grobie św. Marcina, które spisał biskup Perpetuus z Tours. Opatrzone prologiem dzieło ma klasyczną formę heksametryczną, co zakłada niemal nieuniknione naśladowanie wzorów klasycznych; por. T. Gärtner, Zur Christlichen Imitationstechnik in der ,"Vita sancti Martini” des Paulinus von Petricordia, VigCh 55 (2001) 71. 
„Interea ut primum tenebras rarescere noctis

vicina jam luce vident, cum praevia solem

nuntiat acceptum spargens aurora ruborem,

et croceo obnubens pallentia sidera fuco" $"$.

Widać tu znowu elementy, przede wszystkim barwy, które łączą się z tradycyjnym obrazem jutrzenki poprzedzającej słońce i przysłaniającej gwiazdy. Choć nie jest tu ona boginią, a jedynie zjawiskiem naturalnym, to jednak topos został zachowany. Wynika to z konsekwentnego naśladowania przez Paulina poezji świeckiej, pogańskiej, dla potrzeb chrześcijańskiej treści poematu ${ }^{31}$.

Wśród najznakomitszych twórców chrześcijańskiego antyku szczególne miejsce zajmuje Prudencjusz (Aurelius Prudentius Clemens) ${ }^{32}$. Interesujący z punktu widzenia naszych rozważań jest fragment polemicznego utworu poety, powstałego po nakazie cesarza Gracjana, aby z senatu usunięto ołtarz bogini Wiktorii, czemu sprzeciwił się Symmach, stojący na czele poselstwa do władcy w tej sprawie. Prudencjusz w odpowiedzi napisał dzieło przeciwko pogaństwu ${ }^{33}$. Pierwsza księga poświęcona jest krytyce politeizmu, druga, to zbicie argumentacji Symmacha poprzez rozszerzenie argumentacji św. Ambrożego z Mediolanu ${ }^{34}$. Tam też znajduje się fragment, opisujący wszechmiar działania wojny, ukazanej pod postacią bogini Bellony, a cały świat to przestrzeń, którą każdego poranka rozświetla Aurora:

„Omnibus in terris, quas continet occidualis

Oceanus, roseoque aurora illuminat ortu, miscebat Bellona furens mortalia cuncta, armabatque feras in vulnera mutua dextras.

Hanc frenaturus rabiem Deus, undique gentes

Inclinare caput docuit sub legibus iisdem" 35 .

${ }^{30}$ Paulinus Petricordiensis, In sanctum Martinem lib. III 347-350, PL 61, 1035, thum. własne: „Kiedy zaś zobaczyli, jak rzedną nocne ciemności, / bliskim już światłem zwarzone, bo słońca zwiastunka i herold / przyjście jego oznajmia, purpurę rozsiewa przyjemną, / gwiazdy zaś blade przysłania złocisto - czerwonym welonem".

${ }^{31}$ Por. Gärtner, Zur Christlichen Imitationstechnik, s. 71.

${ }^{32}$ Urodził się w Hiszpanii ok. 348 roku, ukończył studia retoryczne, dwukrotnie pełnił urząd namiestnika prowincji, był doradcą cesarza Teodozjusza, by wreszcie poświęcić się wyłącznie poezji chrześcijańskiej, której wydanie sam przygotował w wieku 57 lat; por. M. von Albrecht, Roman Literature. From Livius Andronicus to Boethius. With Special Regard to Its Influence on World Literature, II, Leiden - New York - Köln 1997, 1357.

${ }^{33}$ Por. Cytowska - Szelest, Literatura rzymska, s. 215.

${ }^{34}$ Por. Ambrosius, Epistulae 17-18; Albrecht, Roman Literature, s. 1358.

${ }^{35}$ Prudentius, Contra Symmachum II 2, 597-602, PL 60, 227-228, tłum. własne: „Wszędzie, gdzie ziemię zachodni ocean oblewa bezkresny, / wschód zaś różana oświetla Jutrzenka w promiennych blaskach, / wszystko, co śmierci podległe, Wojna mąciła straszliwa; / zbroić kazała prawice, by rany okrutne zadały. / Wściekłość tę chcąc poskromić Bóg nasz pouczył narody / prawom jednakim poddawać głowy przez ład ujarzmione". 
Aurora, jakkolwiek została pokazana w sposób uproszczony, posiada atrybuty znane z eposów Homera i Wergiliusza: powstaje z roseo ortu, i oświeca świat, podczas gdy na nim działa Bellona, zupełnie jak w homerowych opisach bitew. Ten wergiliański niemal obraz to część szerszego fragmentu (II 2, 578-633), który jest szczególnie istotny z punktu widzenia historycznej koncepcji Prudencjusza mówiącej o posłannictwie Rzymu. Jest to nawiązanie do słów Anchizesa ${ }^{36}$, które poeta traktuje jako zapowiedź obecnej rzeczywistości. Według poety Rzym zajął całą zamieszkałą ziemię i rozszerzył swój pokój, przygotowując $\mathrm{w}$ ten sposób polityczne i kulturalne podłoże pod nauczanie Chrystusa $^{37}$.

Powyższe przykłady pokazują obecność motywu Aurory w poezji chrześcijańskich autorów, wynikającą przede wszystkim z przejmowania wzorców niechrześcijańskich, których poznawanie było oczywistym elementem wykształcenia każdego z prezentowanych twórców. Był to także jeden kod kulturowy, jeden język, operujący nie tylko podobnym zestawem słów, ale także obrazów, sposobów wyrażania myśli. Chrześcijańscy twórcy, których tu przywołano, potraktowali motyw jutrzenki jako oczywisty element poezji, przyjmując go bez większych zmian. Czy jednak chrześcijańska poezja mogła temu staremu toposowi nadać jakieś nowe znaczenie?

2. Aurora w chrześcijańskiej poezji religijnej. Poezja tworzona przez chrześcijańskich autorów nie ograniczała się jednak tylko do wzorowania się na klasykach i wykorzystywania motywów przez nich opracowanych. Wspomniany już Prudencjusz to nie tylko naśladowca Wergiliusza, ale także chrześcijański poeta piszący utwory religijne, przeznaczone do modlitwy. W zbiorze takich właśnie utworów można odnaleźć motyw jutrzenki. W hymnie $A d$ galicinium ze zbioru Cathemerinon widać operowanie symboliką snu jako obrazu śmierci i światła, jako przestrzeni działania Chrystusa ${ }^{38}$ :

„Tectos tenebris horridis, stratisque opertos segnibus, suadet quietem linquere jam jamque venturo die.

Ut cum coruscis flatibus aurora coelum sparserit, omnes labore exercitos confirmet ad spem luminis" ${ }^{\prime 3}$.

\footnotetext{
${ }^{36}$ Por. Publius Vergilius Maro, Aeneis VI 847-853.

${ }^{37}$ Por. S. Döpp, Vergilische Elemente in Prudentius' , Contra Symmachum”, „Hermes” 116 (1988) 341-342.

${ }^{38}$ Por. Cytowska - Szelest, Literatura rzymska, s. 198.

${ }^{39}$ Prudentius, Cathemerinon I 17-24, PL 59, 778-779, tłum. własne: „A kogo grzechu całun skrył / i leży wbity w prochu czerń, / ten głos podnosi, aby żył / i powstał, skoro wstaje dzień. / Aby,
} 
Tutaj nie ma już bogini Aurory, nie ma rydwanu, starca jako małżonka. Pozostaje po prostu jutrzenka jako określenie pory dnia, ale jeśli dzienne światło oznacza Chrystusa, to także jutrzenka zbliża się do innego znaczenia. Poprzedza ona - jak zwykle - nadejście słońca, ale tutaj jego światło to synonim Zbawiciela, a motyw światła i ciemności jest dla całego zbioru Cathemerinon zasadniczy ${ }^{40}$. W powyższym utworze, który nie był raczej przeznaczony do wykonywania w czasie liturgii, wyrażona została zachęta do czujności i duchowej trzeźwości wobec ciągłego niebezpieczeństwa ataku ze strony demona, stąd utwór zakończony jest modlitwą do Chrystusa o pomoc ${ }^{41}$.

Twórczość Prudencjusza poprzedzona została dziełami św. Ambrożego, biskupa Mediolanu, który był niezwykle płodnym pisarzem chrześcijańskim, a także poetą. Powstanie jego hymnów łączy się z historią konfliktu ortodoksyjnego przywódcy Kościoła w Mediolanie z cesarzową Justyną, matką cesarza Walentyniana II, która była arianką. W atmosferze walki religijnej i konieczności okupowania przez wiernych kościoła w Mediolanie Ambroży, wychodząc naprzeciw pewnej psychicznej potrzebie zgromadzonych, dokonał innowacji liturgicznej wprowadzając chóralny śpiew psalmodii i hymnów, jak to miały w zwyczaju Kościoły Wschodu. Taka praktyka, za przykładem Mediolanu, rozprzestrzeniła się także na Zachodzie ${ }^{42}$. Powodzenie hymnów Ambrożego zachęciło innych twórców do naśladowania formy przez niego zaprezentowanej. Naśladowano więc pierwowzór, tworząc w tej samej mierze metrycznej hymny, nazywane potem ambrozjańskimi ${ }^{43}$.

Wśród owych utworów, do dziś obecnych w liturgii Kościoła, można znaleźć kilka, które podejmują także motyw jutrzenki. Pierwszy z nich przeznaczony jest na Wielkanoc, mówi bowiem o zmartwychwstaniu Chrystusa, jakkolwiek został z czasem podzielony na części przypisane innym niż poranna porom dnia $^{44}$ :
„Aurora lucis rutilat, caelum laudibus intonat, mundus exultans iubilat, gemens infernus ululat, cum rex ille fortissimus mortis confractis viribus pede conculcans tartara solvit catena miseros" ${ }^{\prime 5}$.

gdy chyży zgoni wiatr / jutrzenka, nieba świetląc krąg, / posłyszał umęczony świat, / że w wiecznym świetle jest kres mąk".

${ }^{40}$ Por. Albrecht, Roman Literature, s. 1362.

${ }^{41}$ Por. A. Walpole, Early Latin Hymns, Cambridge 1922, 116-117.

${ }^{42}$ Por. A. Bastiaensen, Les Hymnes d'Ambroise de Milan: A propos d'une nouvelle edition, VigCh 48 (1994) 158.

${ }^{43}$ Por. Walpole, Early Latin Hymns, s. 18.

${ }^{44}$ Teksty hymnów oraz ich numerację podano za: Walpole, Early Latin Hymns.

${ }^{45}$ Hymnus 111, 1-8, Walpole, Early Latin Hymns, s. 356, thum. własne: „Jutrzenka czerwień 
Jutrzenka, która czerwieni się o świcie, występuje jako pierwszy sygnał zmartwychwstania, a jej powstanie daje początek ogólnej radości, w której uczestniczy niebo i ziemia, natomiast jako kontrast dla tej radości ukazano lamentujące piekło. Aurora, choć nie jest tu oczywiście boginią, pełni jednak nadal funkcję herolda słonecznego światła, jednocześnie zwiastując triumf Chrystusa.

Jutrzenka w nieco innej, niemal militarnej roli została ukazana na początku hymnu porannego:
„Aurora iam spargit polum ${ }^{46}$,
terris dies illabitur,
lucis resultat spiculum,
discedat omne lubricum" ${ }^{47}$.

Tym razem świt rozprzestrzenia się na niebie niczym żołnierze na polu bitwy, dzień przedostaje się na ziemię, niemal się przekrada, a ukazujące się ostrze światła (spiculum) powinno sprawić, że wycofuje się to, co niepewne, śliskie (lubricum), a zatem niebezpieczne dla człowieka, dla chrześcijanina.

Podobny, choć bardziej rozbudowany, obraz świtu przedstawia inny hymn rozpoczynający się od modlitwy skierowanej do Boga, nazwanego „siewcą światła” (sator lucis), który podtrzymuje niebo swym ramieniem. Dalej następuje konwencjonalny, znany z homeryckiej i rzymskiej epiki obraz jutrzenki, która przysłania gwiazdy, wynurzając się z oceanu, obmywa świat rosą, a na jej widok wycofuje się bez zwłoki poranna gwiazda (Phosphoros):

„Deus, qui caeli lumen es

satorque lucis, qui polum

paterno fultum bracchio

praeclara pandis dextera.

Aurora stellas iam tegit

rubrum sustollens gurgitem,

umectis atque flatibus

terram baptizans roribus.

światu śle, / a chwała płynie z górnych nieb, / radości pełen cały świat, / od piekieł słychać gorzki płacz, / gdy pełen chwały wielki Król, / co skruszył wrogą śmierci moc / i otchłań ciemną zdeptał już, / kajdany zerwał z biednych dusz".

${ }^{46}$ Hymn ten został przeredagowany i funkcjonuje w liturgii ze zmienionym incipitem („Aurora coelum purpurat") wskutek działalności pięcioosobowej komisji, która zajęła się rewizją hymnów używanych w liturgii, czyniąc to na polecenie papieża Urbana VIII w latach 1628-1631; Por. J. Szövérffy, Hymnological Notes: Some Aspects of Hymnological Literature and Hymns of the New Breviary, „Traditio” 25 (1969) 467-469.

${ }^{47}$ Hymnus 72, 1-4, Walpole, Early Latin Hymns, s. 279, thum. własne: ,Jutrzenka w niebo blaski śle, / przenika ziemię jasny dzień, / a gdzie uderzy światła grot, / niech pierzcha wszystko, co jest złe". 
Currus iam poscit Phosphorus

radiis rotisque flammeis,

quod caeli scandens verticem

profectus moram nesciens" $" 48$.

Mimo modlitewnego wstępu, utwór prezentuje epicki obraz, w którym dostrzec można wyraźną personifikację Aurory i porannej gwiazdy, ukazanych jako walczące ze sobą siły, co formalnie odnosi się do tradycji eposu, ale w istocie do chrześcijańskiej idei walki duchowych sił w człowieku ${ }^{49}$, w którym ciemność powinna ustąpić wobec nadchodzącego światła, czyli Chrystusa, nazwanego dies dierum (w. 17) i lucis lumen (w. 18).

Pojawiający się świt to początek dnia i światła, ale też czas modlitwy do Boga u progu codziennych trudów:

„Ecce iam noctis tenuatur umbra,

lucis aurora rutilans coruscat;

nisibus totis rogitemus omnes

cunctipotentem,

ut Deus, nostri miseratus, omnem

pellat angorem, tribuat salutem,

donet et nobis pietate patris

regna polorum" 50 .

W hymnie tym, przypisywanym Grzegorzowi Wielkiemu ${ }^{51}$, ułożonym przez anonimowego autora w strofie safickiej i przeznaczonym do oficjum niedzielnego $^{52}$, nie widać już żadnego rozbudowanego obrazu, a jedynie wprowadzenie do prośby, natomiast jasność jutrzenki napawa nadzieją na jej wysłuchanie.

Podane wyżej przykłady wykorzystania toposu jutrzenki w religijnych utworach chrześcijańskich, często anonimowych, mają swoje źródło - jak to już wyżej stwierdzono - w naśladowaniu hymnów Ambrożego z Mediolanu.

${ }^{48}$ Hymnus 44, 1-12, Walpole, Early Latin Hymns, s. 219-220, thum. własne: „Niebiańskie światło, Boże nasz / i blasku siewco, Twoja moc / ojcowska trzyma nieba dal, / otwierasz je prawicą Twą. / Jutrzenka gwiazdy skryła już, / purpury falę wzbija wraz, / wilgotny powiew ziemi śle, / i kropi je perłami ros. / Zaranna z gwiazd przyśpiesza bieg, / jej rydwan błyska ogniem kół, / bo rusza nieba dognać szczyt, / a zwłoki nie zna pośpiech jej”.

${ }^{49}$ Por. Walpole, Early Latin Hymns, s. 220.

${ }^{50}$ Hymnus 70, 1-8, Walpole, Early Latin Hymns, s. 276, tłum. własne: „Oto już bledną nocy ciemności, / złota jutrzenka blaski rozsiewa, / z całej więc siły wszyscy błagajmy / Wszechmogącego: // niechaj nad nami Bóg się zmiłuje, / odpędzi zamęt, a da zbawienie, / Ojcowska miłość niech nam otworzy / bramy królestwa".

${ }^{51}$ Postać Grzegorza Wielkiego wiązano z reformą liturgii, przypisując mu także utwory poetyckie, przeznaczone dla tychże celów; por. E.S. Duckett, Gateway to the Middle Ages: Monasticism, Michigan 1988, 201-202.

${ }^{52}$ Por. I.B. Milfull, The Hymns of the Anglo-Saxon Church: A Study and Edition of the „Durham Hymnal", Cambridge 1996, 126. 
Jeden z jego utworów, jakkolwiek wcześniejszy od wszystkich zaprezentowanych przykładów, idzie najdalej z nich w interpretacji motywu aurory. Należy tu zaznaczyć, że hymny Ambrożego są połączeniem wielu tradycji literackich. Czerpią one z poezji hymnicznej Horacego (ody horacjańskie i Carmen saeculare), z lirycznych, modlitewnych fragmentów Aeneis Wergiliusza (zwłaszcza z księgi VIII) i z religijnych tekstów wschodnich, także niechrześcijańskich. Oczywisty jest wpływ poezji Hilarego z Poitiers, związanej także z apologią chrześcijaństwa, ale jako główne źródło należy wskazać liryczną poezję psalmów, interpretowanych na sposób chrześcijański ${ }^{53}$. Proste metrum, dymetr jambiczny akatalektyczny, umożliwiające śpiew hymnów, zostało połączone $\mathrm{z}$ tematem korespondującym z liturgią ${ }^{54}$.

Wspomniany hymn, który zaliczany jest do autentycznych dzieł Ambrożego ${ }^{55}$, to utwór Splendor paternae gloriae. Jego pierwsze dwie strofy, skierowane do Chrystusa, określają go przez metaforę światła i dnia, jednocześnie prezentując obraz Trójcy Świętej:

„Splendor Paternae gloriae,

de luce lucem proferens,

lux lucis et fons luminis

dies dierum illuminans,

verusque sol inlabere,

micans nitore perpeti,

iubarque sancti Spiritus

infunde nostris sensibus" ${ }^{\prime 56}$.

Chrystus został tu określony przez szereg efektownych określeń, zaczerpniętych z Biblii, zwłaszcza z początku Listu do Hebrajczyków, gdzie z kolei jest odniesienie do Księgi Mądrości, widać tu jednak także wykorzystanie terminologii klasycznej ${ }^{57}$. Relacja Ojca do Syna została zobrazowana przez częsty u pisarzy chrześcijańskich obraz promienia światła w odniesieniu do źródła, z którego płynie ${ }^{58}$. Widać tu zbieżność motywów antycznych i obrazów biblijnych, które często odnoszą się do antytezy światła i ciemności (np. Iz 9, 1 cytowany przez Mt 4, 16; dalej odnoszace się wprost do Chrystusa - Łk 1 , 78; 2, 32; J 1, 4-5. 9; 8, 12). Określenie Chrystusa jako verus sol jest także

\footnotetext{
${ }^{53}$ Por. Bastiaensen, Les Hymnes d'Ambroise de Milan, s. 158.

${ }^{54}$ Por. T. Gacia, „Przyodziej ciała trofeum...”. Soteriologia hymnów św. Ambrożego, VV 1 (2002) 227.

${ }^{55}$ Por. Walpole, Early Latin Hymns, s. 35.

${ }^{56}$ Hymnus 3, 1-8, Walpole, Early Latin Hymns, s. 35-36, tłum. własne: „O, wieczny blasku Ojca chwał, / ze światła czerpiesz światło wraz, / Tyś źródło światła, Tyś sam blask, / jaśnieje w Tobie wieczny dzień. / Prawdziwe Słońce, w dusze wnijdź / i rozpal wiecznym światłem je, / Świętego Ducha ogień też / w umysły nasze hojnie wlej”.

${ }^{57}$ Por. Gacia, ,Przyodziej ciała trofeum... ”, s. 229.

${ }^{58}$ Por. Walpole, Early Latin Hymns, s. 35.
} 
odniesieniem do idei chrystianizacji pogańskiego kultu solarnego ${ }^{59}$. Rodzaj klamry wobec początku hymnu stanowi jego zakończenie, w którym pojawia się aurora:
„Aurora cursus provehit, aurora totus prodeat, in Patre totus Filius, et totus in Verbo Pater" ${ }^{\prime 60}$.

Klasyczny rzeczownik cursus przywodzi na myśl Wergiliusza i jego obraz bogini Aurory, powożącej zaprzęgiem, z pośpiechem pokonującej swą drogę ${ }^{61}$. $\mathrm{Z}$ drugiej jednak strony niespotykane połączenie aurora totus, sugeruje, że rodzaj przymiotnika został dostosowany do innego niż zazwyczaj podmiotu. $\mathrm{W}$ tej strofie aurora totus należy zestawić z totus Filius, ponieważ to o Syna tu chodzi $^{62}$. Aurora zatem występuje tu jako metaforyczne określenie Chrystusa, nazwanego na początku hymnu słońcem ( $\mathrm{sol}$ ), które podnosi się, a więc nie jest jeszcze widoczne, dopiero ma powstać, stąd skierowany do niego czasownik prodeo, użyty tu $\mathrm{w}$ modus coniunctivus ${ }^{63}$. Może to być odniesienie zarówno do zmartwychwstania, jak i do paruzji ${ }^{64}$. Trzykrotne określenie totus podkreśla także jedność Trójcy Świętej, co wynika z antyariańskiego charakteru całego hymnu ${ }^{65}$.

Należy na koniec podkreślić, że przedstawienie Chrystusa jako jutrzenki jest najbardziej śmiałym zabiegiem poetyckim, z jakim można się spotkać $\mathrm{w}$ odniesieniu do tego motywu $\mathrm{w}$ dotychczasowej poezji chrześcijańskiej. Epicki topos, który od Homera był obecny w literaturze, przeszedł nie tylko do poezji chrześcijańskiej, ale także do tekstu religijnego, modlitewnego, zyskując zupełnie nowe znaczenie, otwierając tym samym drogę dla nowej, chrześcijańskiej interpretacji starego motywu.

${ }^{59}$ Por. Gacia, „Przyodziej ciała trofeum..., s. 230. Kult Słońca Niezwyciężonego (Sol invictus) został zaprowadzony w Rzymie przez cesarza Aureliana w 2. poł. III w. Wiązało się to z polityką religijną cesarza, pragnącego scalić Imperium. Chciał on być uważany za przedstawiciela boga Słońca na ziemi, zbudował dla niego świątynię i ustanowił kapłańskie kolegium (pontifices solis); por. M. Jaczynowska - M. Pawlak, Starożytny Rzym, Warszawa 2008, 302.

${ }^{60}$ Hymnus 3, 29-32, Walpole, Early Latin Hymns, s. 39, thum. własne: „Jak zbliża się wschodzący świt, / niech Świt ten w pełni wzejdzie nam, / tak w Ojcu pełnię swą ma Syn, / a Ojciec pełnię w Słowie ma".

${ }^{61}$ Por. Publius Vergilius Maro, Aeneis VI 535-536, ed. Ribbeck, s. 236: „Roseis Aurora quadrigis / iam medium aetherio cursu traiecerat axem”, thum. własne: „Różanym Jutrzenka zaprzęgiem / wjeżdża, by drogę niebiańską przebyć lotnym powozem.

${ }^{62}$ Por. Walpole, Early Latin Hymns, s. 39.

${ }^{63}$ Por. Gacia, ,Przyodziej ciała trofeum..., s. 231.

${ }^{64}$ Por. tamże.

${ }^{65}$ Por. tamże, s. 229. 
Powyższa, z konieczności jedynie pobieżna prezentacja ukazuje jednak wyraźnie oczywistą zależność poezji chrześcijańskiej od pogańskiego dziedzictwa $z$ jednej strony, ale jednocześnie umiejętność jego przepracowania. Twórcy poezji, którą można określić jako imitatio naśladowali dawne schematy bez ich modyfikowania, jak to widać wyraźnie choćby u Sydoniusza Apolinarego. Także dzieła pisane z wyraźnie chrześcijańskiego punktu widzenia, jak to ma miejsce u Drakoncjusza, zawierają obrazy i schematy zaczerpnięte z epiki rzymskiej, czy wcześniej z Homera, ukazując interesujący nas motyw jutrzenki w niezmienionym kształcie, choć czytelnik wyczuwa, że odwołanie się do mitu nie jest tu już obecne, ponieważ aurora to jedynie element konwencjonalny. Nowe ujęcie motywu, wiązało się z nowym rodzajem poezji, nowym nie ze względu na formę metryczną, ale ze względu na cel, jakim była modlitwa i medytacja nad tajemnicami wiary chrześcijańskiej. Tutaj widać, że utarty schemat zyskuje nową jakość, ponieważ nie jest już tylko konwencjonalnym toposem, ale odwołaniem się do głębszej warstwy znaczeniowej, co najbardziej widać w zestawieniu Aurora - Chrystus. Istotnym zjawiskiem, z jakim mamy tu do czynienia, jest więc stopniowe przesuwanie się pola znaczeniowego motywu jutrzenki, którego dalszy ciąg można obserwować w późniejszej o całe wieki poezji religijnej, w której jutrzenka jest utożsamiana z Maryją. Przybliżenie tego zjawiska wymagałoby jednak dalszych, szerszych badań.

\section{THE THEME OF DAWN IN ANCIENT CHRISTIAN POETRY}

\section{(Summary)}

The theme of Dawn, which is present in the epics of Homer and later on in the poetry of Vergil and Ovid, was also present in ancient Christian poetry. This, on one side was due to ancient education, that included works by classical authors. On the other side, it resulted from the desire by Christian artists to mimic pagan masters. The theme of dawn is an example of acquasition of poetic patterns, but it also shows the original thought of Christian poets who gave it new meaning, identifying the Aurora with Christ. ligijny.

Słowa kluczowe: motyw Aurory, opis świtu, poezja chrześcijańska, hymn re-

Key words: theme of Aurora, description of dawn, Christian poetry, religious hymn. 